\title{
Diphasic Liquid Systems and Bio-electrical Phenomena.
}

\author{
BY
}

\section{DOROTHY HAYNES,}

Deparlment of Plant Physiology and Pathology, Imperial College of Science and Technology.

$T^{\prime}$ HE writer is glad to have the opportunity of replying to Dr. Beutner's paper in this Journal (pp. 673-7). It is felt that certain points have been left somewhat obscure, and it is desired to revise one or two statements which as they stand are incorrect. Dr. Beutner complains of various misrepresentations ; the writer much regrets if she has misunderstood any material point, but as Dr. Beutner avoids all detail of these it is impossible to ascertain the grounds of his complaint. In dealing with the specific questions which he has brought forward it has been thought useful to summarize briefly the points at issue.

The difficulty in dealing with Dr. Beutner's systems lies in the fact that they are not in true equilibrium. It had been assumed in the original criticism that in the case of non-acid oils equilibrium is rapidly reached at the surface, but beyond this there exists a small zone into which soluble salt diffuses. In a recent review of some part of Dr. Beutner's work Gardner ${ }^{1}$ interprets his results on the assumption that the penetration of electrolytes is strictly confined to the surface layer; this accounts for the rapid establishment of equilibrium which Dr. Beutner observed as well as for the numerical results he obtained, but it is difficult to reconcile the assumption with a distribution by diffusion, and it is interesting to notice that Baur, ${ }^{1}$ working on similar lines, has adopted an adsorption formula. It may be suggested, however, that rapid diffusion may quite possibly be confined to a thin film into which water penetrates, since Dr. Beutner's measurements of potential appear to have been carried out on dry oils, while his estimates of concentration were deduced from changes of conductivity in these oils after they had been shaken up with aqueous solutions. It should be remarked that it was not intended to suggest that Dr. Beutner denied

1 Fourth Report on Colloid Chemistry, p. ir6, Brit. Assoc.

Annals of Botany, Vol. XXXVII. No. CXLVII. October, 1923.] 
the possibility of a diffusion poteritial in oils-criticism was directed to the fact that he regards it as negligible throughout his systems.

In the previous paper criticism was mainly directed to those systems which contain free acid in the oil phase. It is felt that sufficient emphasis was not laid upon the fact that all Dr. Beutner's measurements of solubility depend upon changes of conductivity in oils saturated with water, and that where chlorides or salts of other mineral acid react with organic acid present in the oil phase, much of the increased conductivity may be due to increase in the concentration of hydrogen ions. For this reason it is unlikely that Dr. Beutner's measurements afford any true indication of the concentrations of sodium ions in the 'oil' phase. At boundaries where the sodium salt of an organic acid is present this difficulty does not arise, and Dr. Beutner's assumption that the change of conductivity is principally due to increase of sodium ions may well be justified. Since sodium ions are present in large excess, the interphasic potential will be determined by the solubility of the sodium salt ; the writer's previous criticisms on this point are therefore not valid. In reversible conditions the interphasic potential will be measured by the distribution of the sodium ion, since this is common to the two phases; therefore, given reversibility, the formula holds good at this boundary; but it is hardly admissible to regard such systems as reversible, and diffusion potentials probably contribute to the total E.M.F.

In the original criticism it was suggested that the E.M.F. of reversible systems of the type

$$
\begin{array}{c|c|c}
\mathrm{KCl} & \mathrm{Acid} & \mathrm{KCl} \\
\mathrm{C}_{1} & \text { oil } & \mathrm{C}_{2}
\end{array}
$$

may be due to a difference of hydrogen-ion concentration on either side of an oil phase in which hydrogen-ion concentration is constant. Dr. Beutner attempts to disprove this suggestion by comparing the E.M.F. of the system

$$
\begin{array}{c|c|c}
\text { salicylic acid } & \begin{array}{c}
\text { oil saturated with } \\
\text { salicylic acid }
\end{array} & \begin{array}{c}
\text { salicylic acid } \\
\mathrm{KCl}
\end{array}
\end{array}
$$

with the $\mathrm{pH}$ values of the two aqueous solutions. He has, however, left out of consideration the fact that the equilibrium

$$
\mathrm{KCl}+\mathrm{C}_{6} \mathrm{H}_{4}(\mathrm{OH}) \mathrm{COOH} \rightleftarrows \mathrm{C}_{6} \mathrm{H}_{4}(\mathrm{OH}) \mathrm{COOK}+\mathrm{HCl}
$$

will be disturbed by the introduction of the oil phase, which will not only act as a reserve of acid but will also tend to dissolve undissociated potassium salicylate. On both accounts the equilibrium will be displaced to the right, and it is probable that a very considerable increase of hydrogenion concentration will result. This, however, cannot account for the whole difference of potential observed in the above system, and a consideration of this system has drawn attention to the fact-the importance of which has been overlooked both by Dr. Beutner and the present writer-that potassium 
ions may very probably be maintained in the oil at a nearly constant concentration, while transference of potassium ions takes place mainly as undissociated salt. If this be an adequate explanation, Dr. Beutner may fairly claim justification for the view that the solubility of salts is the predominating factor in the production of differences of potential in his systems, although the differences of hydrogen-ion concentration which arise must also be taken into account; but his quantitative results must in this case be entirely invalidated, since changes of conductivity will be mainly due to the production and solution of hydrogen chloride. Moreover, as has been already remarked, there appears in many cases to be no adequate reason for assuming the absence of a diffusion potential.

On more general questions there is little to be added to what has already been said - the value of an adequate model of the cell in its electrochemical relations cannet be doubted, but until we know more of cell mechanism the attempt to construct such a model would appear premature and liable to mislead. This is said with no desire to underrate the value of attempts to draw analogies between physical and biological systems; such analogies constitute the chief hope of advance upon the biological side, but it must be remembered that their interpretation is beset with all the difficulties which arguments from analogy admittedly encounter. Dr. Beutner attaches great importance to Macdonald's experiments on dissected nerves. It may well be true that the nerve-sheath, which is known to contain much lipoid substance, plays a part similar to that of the waxy cuticle of the apple, and that Dr. Beutner's acid-oil systems are typical of both. This is undoubtedly important, but since both of these are very special structures it is hardly a justification for the assumption that the differences of potential at all cell surfaces are solely conditioned by differential solubility in a lipoid layer which contains free acid, especially in view of the fact that the lipoid theory has been universally rejected by physiologists after a very large amount of investigation. Dr. Beutner's treatment of the 'current of injury', and the fact that he deduces the distribution of fatty acid in the apple from this phenomenon, are evidence of the large claim of universal validity which he makes for his hypothesis. It should perhaps be added that the statement as to a homogeneous 'flesh' to which Dr. Beutner objects was based on his treatment of the 'flesh' as a separate phase. 


\section{$2 \mathrm{BHL}$ Biodiversity Heritage Library}

Haynes, Dorothy. 1923. "Diphasic liquid systems and bio-electrical phenomena." Annals of botany 37, 679-681. https://doi.org/10.1093/oxfordjournals.aob.a089873.

View This Item Online: https://www.biodiversitylibrary.org/item/270686

DOI: https://doi.org/10.1093/oxfordjournals.aob.a089873

Permalink: https://www.biodiversitylibrary.org/partpdf/319109

\section{Holding Institution}

New York Botanical Garden, LuEsther T. Mertz Library

\section{Sponsored by}

BHL-SIL-FEDLINK

\section{Copyright \& Reuse}

Copyright Status: Public domain. The BHL considers that this work is no longer under copyright protection.

This document was created from content at the Biodiversity Heritage Library, the world's largest open access digital library for biodiversity literature and archives. Visit BHL at https://www.biodiversitylibrary.org. 